\title{
HOLY GRANDEUR ENOUGH FOR ALL ${ }^{1}$
}

\author{
Novrianna Gloria Hutagalung*
}

\begin{abstract}
Natural degradation is not merely a competition between ecology and economy. The destruction of nature is closely related to religiosity and human relationships to fellow human beings, the environment, and God. Ecotheology becomes a self-criticism of the classical doctrines of Christianity, which are considered to exalt humankind as the "crown of creation" and marginalize non-human creatures as commodities of economic value for human interests. Ecotheology seems to have talked too often about damaged nature, or even extinct plants or animals, and forgetting the other side of the bountiful biodiversities, which is the holy beauty of nature. Ecotheology needs to ponder that God, the Holy Grandeur, who manifests the cosmic wisdom in the beauty of all creation, is enough for all.
\end{abstract}

Keywords: Holy Grandeur, Sophia, ecotheology, Eastern Orthodox, holy beauty.

\begin{abstract}
Abstrak
Degradasi alam bukan semata-mata persaingan antara ekologi dan ekonomi. Kerusakan alam sangat terkait dengan religiositas dan relasi manusia terhadap sesama manusia, lingkungan sekitar, dan Allah. Ekoteologi menjadi sebuah otokritik atas doktrin-doktrin klasik Kristen yang dianggap telah meninggikan manusia sebagai ciptaan termulia dan meminggirkan ciptaan non-manusia sebagai komoditas bernilai ekonomis bagi kepentingan manusia. Ekoteologi tampaknya terlalu sering berbicara mewakili alam yang rusak, tumbuhan, dan hewan-hewan yang telah punah atau bahkan rusak, dan melupakan sisi lain dari keanekaragaman alam semesta, yakni keindah-kudusan alam itu sendiri. Ekoteologi perlu

* Mahasiswi Sekolah Tinggi Filsafat Theologi Jakarta (STT Jakarta). Email: borugalung@gmail.com

C NOVRIANNA GLORIA HUTAGALUNG ｜ DOI: 10.21460/gema.2017.22.317
\end{abstract}

This work is licenced under a Creative Commons Attribution-NonCommercial 4.0 International Licence. 
merenungkan bahwa Allah, Sang Semarak Kudus, yang memanifestasikan hikmat-kosmis dalam keindah-kudusan seluruh ciptaan, cukup untuk segala ciptaan dalam kelimpahruahan.

Kata-kata kunci: Semarak-Kudus, Hikmat-Kosmis, ekoteologi, Orthodoks Timur, indahkudus.

\section{PENDAHULUAN}

Bumi adalah sebuah keterjalinan raksasa yang di dalamnya manusia memiliki konteksnya. Biodiversitas (keanekaragaman hayati) merupakan kesatuan kehidupan yang kompleks, terdiri dari berbagai jenis makhluk hidup, di suatu kawasan tertentu, baik di darat maupun di laut. Biodiversitas menunjukkan adanya keterhubungan antar seluruh makhluk. Setiap komponen dalam alam semesta memiliki tugas masing-masing. Menjaga kelestarian alam menjadi penting karena setiap makhluk hidup memiliki ketergantungan dan keterkaitan dengan makhluk lainnya.

Cara manusia memperlakukan alam bergantung pada hubungan diri mereka sendiri dengan lingkungan di sekitar mereka. Penangkapan ikan yang berlebihan dan bersifat destruktif, pembukaan lahan hutan bagi pemukiman penduduk, pariwisata yang tidak ramah lingkungan, dan pemanasan global merupakan faktor yang dapat membawa dampak negatif bagi lingkungan hidup (WWF website, 2010). Sebagai contoh, pemanasan global menyebabkan suhu air laut turut meningkat. Terumbu karang, yang merupakan tempat tinggal bagi ikan dan biota laut lainnya, tidak dapat bertahan hidup di suhu yang terlalu panas, memutih, dan akhirnya mati. Pada saat yang sama, terumbu karang yang mati berdampak pada ikan-ikan yang akan sulit bertahan hidup. Hal ini merupakan contoh kecil yang menunjukkan keterjalinan makhluk hidup yang satu dengan yang lainnya. Dengan mengabaikan kepentingan non-manusia dan rangkaian rantai kehidupan yang terjadi, seakan-akan menunjukkan bahwa manusia adalah puncak dari rantai makanan yang terjadi dan segala makhluk non-manusia bermanfaat demi kelangsungan hidup manusia saja.

Sejak munculnya tulisan Lynn White Jr. pada tahun 1967, para teolog Kristen mulai melihat adanya keterkaitan antara pemahaman iman Kristen dengan lingkungan hidup. Pemahaman manusia mengenai relasinya dengan lingkungan hidup berhubungan dengan pemahaman manusia mengenai dirinya sendiri. Apabila manusia melihat dirinya bukan bagian dari lingkungan, maka manusia pun akan memperlakukan alam sebagai objek yang harus dimanfaatkan sesuai dengan kebutuhan manusia itu sendiri. 
Ekoteologi muncul sebagai upaya untuk merekonstruksi ajaran-ajaran Kristen yang memperlakukan seluruh ciptaan dan alam semesta sebagai komoditas bernilai ekonomis bagi kepentingan manusia saja. Di dalam makalah ini, saya akan mengulas tulisan klasik dalam diskursus ekoteologi yang ditulis oleh Lynn White Jr., yakni artikel berjudul "The Historical Root of Our Ecological Crisis," dan memaparkan kritik ekoteologi terhadap doktrin penciptaan yang berdampak destruktif terhadap alam. Saya pun akan membahas pemikiran teolog konstruktif Gordon D. Kaufman yang memahami Allah sebagai Kreativitas-Tak-Terduga (Serendipitious Creativity). Kemudian, saya akan membahas pemikiran Bruce Foltz mengenai keindah-kudusan alam (holy beauty of nature). Lalu, saya akan melirik tradisi Sophia dalam Kekristenan Orthodoks untuk memahami HikmatKosmis. Akhirnya, saya mengajak pembaca untuk bersama-sama merenungkan bahwa Allah, Sang Semarak Kudus, cukup bagi segala, termasuk ciptaan terkecil sekalipun.

\section{KEPUTUSASAAN TEOLOGI}

Kerusakan alam sangat terkait dengan religiositas dan relasi manusia dengan sesama manusia, lingkungan sekitar, dan Allah. Pada tahun 1967, Lynn White Jr., seorang ahli sejarah abad-abad pertengahan, menulis artikel berjudul "The Historical Root of Our Ecological Crisis" yang dimuat dalam jurnal Science. Artikel ini menjadi tulisan yang sangat memengaruhi pemikiran kontemporer mengenai lingkungan hidup. Sejak diterbitkan dalam jurnal tersebut, tulisan White dicetak ulang dalam berbagai publikasi dan telah memengaruhi dua generasi orang-orang yang memiliki concern terhadap lingkungan (Foltz, 2014: 74). White menyatakan bahwa perubahan peradaban manusia memengaruhi lingkungan dan makhluk selain manusia (White, 1967: 1203). White melihat pemakaian mesin pembajak sawah sebagai salah satu contoh penemuan teknologi yang memengaruhi hubungan antara manusia dengan tanah. Sebelum mesin pembajak mulai banyak digunakan, petani mengolah tanah dan sawah sesuai dengan kemampuan mereka memiliki kerbau untuk membajak sawah tersebut. Artinya, tanah yang diubah menjadi persawahan pun dalam jumlah terbatas. Hasil panen sawah dimanfaatkan sebagai sumber makanan keluarga para petani. Penemuan mesin pembajak sawah membuat petani berorientasi pada hasil produksi sawah. Hasil panen tidak lagi dimanfaatkan sebagai sumber makanan, tetapi juga sumber penghasilan. Semakin banyak sawah, semakin banyak hasil panen, semakin banyak pula penghasilan yang didapatkan. White menuliskan, "Formerly man had been part of nature; now he was the exploiter of nature" (White, 1967: 1205). 
White menyatakan bahwa:

"What people do about their ecology depends on what they think about themselves in relation to things around them. Human ecology is deeply conditioned by beliefs about our nature and destinythat is, by religion.... What did Christianity tell people about their relations with the environment?" (White, 1967: 1205).

White berpendapat bahwa pemahaman hubungan manusia dengan lingkungan dipengaruhi oleh pengajaran agama, khususnya Kristen. Ia melihat bahwa kekristenan mewarisi konsep penciptaan dari agama Yahudi. Allah yang Mahakuasa dan Mahakasih menciptakan terang dan gelap, bumi dan segala isinya, tumbuh-tumbuhan, berbagai hewan, ikan dan burung. Akhirnya, Allah menciptakan manusia. Lalu, manusia menamai seluruh hewan. White memandang hal ini sebagai penegasan dominasi manusia atas ciptaan non-manusia. "God planned all of this explicitly for man's benefit and rule: no item in the physical creation had any purpose save to serve man's purposes. And, although man's body is made of clay, he is not simply part of nature: he is made in God's image" (White, 1967: 1205).

White menegaskan secara eksplisit bahwa kekristenan, khususnya kekristenan Barat, adalah agama yang paling antroposentris yang pernah ada di dunia (White, 1967: 1205). Manusia dianugerahi natur transenden Allah. Tanpa disadari, kekristenan secara "tidak sengaja" membangun perspektif dualisme antara manusia dan alam. Kekristenan juga menekankan bahwa eksploitasi atas alam demi keberlanjutan hidup manusia merupakan kehendak Allah sendiri.

Hadirnya kekristenan menggantikan agama-agama primal membuat pemahaman agama primal yang naturalistik atau dekat pada alam terpinggirkan dan tergantikan oleh ajaran kekristenan yang mengajarkan kekuasaan manusia atas ciptaan non-manusia. Agama-agama primal memercayai bahwa setiap pohon, setiap musim, setiap sungai, setiap bukit memiliki "genius loci" atau rohroh pelindung (White, 1967: 1205). Ketika seseorang akan menebang pohon, membuka sebuah lahan, membuat bendungan, maka penting untuk melakukan proses "pendamaian" dengan rohroh pelindung tersebut. Kedekatan spiritual terhadap alam ini hilang dan digantikan dengan rasa ketidakacuhan ketika agama-agama primal "disingkirkan” oleh kekristenan.

Namun demikian, White menjelaskan perbedaan antara kekristenan Barat dan kekristenan Timur. Kekristenan Timur meyakini bahwa dosa adalah kebutaan intelektual dan keselamatan dapat ditemukan dalam pikiran yang jernih. Sementara, kekristenan Barat memahami bahwa dosa adalah kejahatan moral dan keselamatan dapat ditemukan dalam tindakan yang baik. White menyebut teologi Orthodoks sebagai intellectualist dan teologi Latin sebagai voluntarist. Santo dari kekristenan Timur berkontemplasi, santo dari kekristenan Barat bertindak. Ia menyimpulkan 
bahwa implikasi kekristenan yang merusak alam lebih mudah berkembang di atmosfer kekristenan Barat daripada di Timur. Tradisi kekristenan Timur meyakini bahwa Allah berbicara kepada manusia melalui alam. White menyatakan, “[Orthodox's] view of nature was essentially artistic rather than scientific" (White, 1967: 1206).

Menurut White, peradaban manusia saat ini, termasuk sains dan teknologi, berkembang dalam era yang disebutnya the post-Christian age (White, 1967: 1205). Saya memahami bahwa hal ini juga merupakan dampak dari kolonialisasi bangsa-bangsa Eropa dengan semboyan terkenalnya-gold, glory, gospel. Ia menyatakan bahwa, "For nearly two millennia Christian missionaries have been chopping down sacred groves, which are idolatrous because they assume spirit in nature" (White, 1967: 1206).

White berpendapat bahwa manusia akan terus memperburuk krisis ekologis hingga manusia menolak pandangan kekristenan yang menganggap bahwa "nature has no reason for existence save to serve man" (White, 1967: 1207). Ia memberikan alternatif teologis dengan melihat sosok St. Fransiskus dari Asisi yang memandang bahwa seluruh ciptaan itu sama (equal), termasuk manusia, sebagai pengganti pandangan yang melihat dominasi manusia atas ciptaan. Oleh karena, menurut White, "the roots of our [ecological] trouble are so largely religious, the remedy must also be essentially religious" (White, 1967: 1207).

Sebagian besar tulisan mengenai hubungan antara krisis ekologis dan respons kekristenan terhadapnya menyatakan bahwa doktrin penciptaan berpengaruh besar pada kerusakan alam dan berbagai eksploitasi terhadap alam (Gschwandtner, 2012: 165). Doktrin penciptaan secara eksklusif berbicara tentang manusia sebagai satu-satunya makhluk yang diciptakan di dalam gambar Allah untuk menguasai alam demi keperluan dan kepentingan manusia. Alam dan makhluk ciptaan non-manusia dipandang sebagai "pelengkap" dari teater ilahi. Alam dan makhluk non-manusia termarjinalkan, baik dalam doktrin maupun dalam praktik hidup Kristen. Berbagai tafsiran yang muncul mengandaikan bahwa manusia memang memiliki hak untuk mendominasi alam semesta.

Kitab Perjanjian Lama banyak bercerita bahwa setiap ciptaan dan bukan hanya manusia dapat memuliakan Allah dengan cara mereka masing-masing yang tersembunyi dari kasat mata manusia (Migliore, 2014: 115). Selama belum disadari, bahwa bukan hanya manusia yang berharga di mata Allah, tetapi juga seluruh ciptaan, seluruh keanekaragaman hayati yang ada di seluruh dunia, maka selama itu pula ciptaan non-manusia akan berada dalam posisi yang terpinggirkan dalam karya Allah.

Narasi penciptaan dalam kitab Kejadian perlu ditafsir sebagai penegasan bahwa Allah bukanlah Dia yang memerintah dengan kuasa dan diktatorial, tetapi Allah yang penuh cinta dan 
anugerah (Migliore, 2014: 115). Alam yang kita lihat dalam kenyataan sehari-hari perlu dipandang dalam kepenuhan sebagai bagian dari ciptaan Allah. Jika alam adalah ciptaan Allah, maka selamanya alam berada di bawah kepemilikan Allah semata-mata dan tidak bisa diklaim oleh siapa pun (Moltmann, 1985: 30). Manusia mendapatkan tanggung jawab penatalayanan (stewardship) untuk berkuasa atas segala bentuk perawatan dan pemeliharaan terhadap alam ciptaan dan bukan kuasa untuk "memakai" saja.

Paham antroposentrisme dan tafsiran yang keliru terhadap narasi dalam pasal pertama kitab Kejadian menunjukkan bahwa manusia belum memahami dan menerima keterhubungan dan ketergantungan dalam segala bentuk kehidupan yang ada di muka bumi ini. Eksploitasi besarbesaran terhadap alam menunjukkan bahwa manusia belum menghargai keberadaan dan nilai dari ciptaan non-manusia (Migliore, 2014: 112). Alam hanya berharga selama memberikan manfaat bagi kehidupan manusia. Padahal, di sisi lain, keanekaragaman hayati menunjukkan bahwa makhluk hidup sangat bergantung satu sama lain, seperti ikan tidak bisa hidup tanpa terumbu karang, demikian pula manusia tidak dapat hidup tanpa lingkungan sekitarnya. Mengkritik tafsiran ini, Robert Borrong berpendapat bahwa Kejadian 1:26-28 tidak dapat ditafsir sebagai mandat untuk menguasai bumi semata-mata. Mandat dalam Kejadian 1:26-28 justru mengandung makna agar manusia memelihara bumi (Borrong, 2005: 142).

Dalam ensikliknya, Laudato Si', Paus Fransiskus menyatakan bahwa manusia telah merusak Bumi melalui penggunaan sumber daya alam yang tidak bertanggung jawab. Manusia memandang dirinya sebagai tuan atas Bumi ini. Bagi Paus Fransiskus, manusia masih memiliki kemampuan untuk bekerja sama membangun dan menjaga kelestarian Bumi, yang disebutnya sebagai “our common home”. Usaha menjaga kelestarian Bumi, mau tidak mau, membutuhkan kerja sama integral dari setiap pihak dan dari segala dimensi kehidupan (Francis, 2015: 45). Setiap ciptaan saling terhubung antara yang satu dengan yang lain. Kepedulian manusia terhadap kelestarian alam juga terkait pada permasalahan ketidakadilan dan penindasan (Francis, 2015: 52). "The entire material universe speaks of God's love, his boundless affection for us. Soil, water, mountains: everything is, as it were, a caress of God" (Francis, 2015: 61). Seluruh ciptaan memiliki manifestasi Allah di dalamnya.

Willis Jenkins, dalam buku Ecologies of Grace (2010), mengelompokkan ekoteologi ke dalam tiga strategi yang menyuarakan suara untuk menyelamatkan alam, yakni: strategy of ecojustice, strategy of Christian stewardship, dan strategy of ecological spirituality. Strategy of ecojustice memerhatikan aspek teologis ciptaan dalam etika lingkungan hidup Kristen (Jenkins, 2010: 61). Strategy of ecological spirituality menekankan posisi manusia, baik secara fisik maupun spiritual, di dalam alam semesta (Jenkins, 2010: 93). Saya ingin menekankan strategy of Christian 
stewardship karena menurut saya strategi ini paling sering dilihat sebagai solusi yang "ideal" untuk merespons krisis ekologis.

Stewardship atau penatalayanan dianggap menjadi salah satu jawaban terhadap perintah Allah dalam Kejadian 1:26-28. Allah mempercayai manusia untuk bertanggung jawab atas seluruh ciptaan dan bukan semata-mata untuk memanfaatkan atau menguasainya. Allah mengundang manusia ke dalam relasi penuh cinta Trinitas bersama dengan seluruh ciptaan. Sebab itu, strategy of Christian stewardship adalah ajakan Allah kepada manusia untuk memedulikan ciptaan nonmanusia (Jenkins, 2010: 77-92).

Peet J. van Dyk mengkritik konsep stewardship sebagai solusi ideal karena terkesan masih mementingkan peran manusia. Ekoteologi tidak menjawab persoalan krisis ekologis karena telah meneguhkan pentingnya posisi manusia dalam keutuhan dan penatalayanan ciptaan. Ia mengkhawatirkan bahwa konsep stewardship merupakan bentuk dominasi dan arogansi manusia atas alam semesta secara tak langsung. Ekologi kontemporer menunjukkan bukti ilmiah bahwa alam tidak selalu membutuhkan interferensi manusia (van Dyk, 2011: 531).

Van Dyk menolak bahwa ekosistem yang baik hanya dapat terwujud dengan campur tangan manusia secara berkala (van Dyk, 2011: 532). Penatalayanan alam oleh manusia seakan menekankan bahwa manusia adalah satu-satunya yang dapat menyelamatkan bumi dan menjaga keutuhan ciptaan. Padahal dengan berasumsi bahwa manusia selalu tahu yang terbaik untuk alam, sering membuat manusia tidak melihat dampak negatif yang justru ditimbulkan oleh interferensi manusia terhadap berbagai aktivitas alam, meskipun interferensi tersebut bertujuan baik dan dilakukan atas nama penatalayanan ciptaan.

Pemikiran Peet J. van Dyk menjadi otokritik yang penting bagi ekoteologi. Ia menunjukkan bahwa teologi lingkungan hidup masih terjebak dalam paham antroposentrisme. Artinya, alam perlu diselamatkan dari berbagai kerusakan yang terjadi bukan karena kepentingan alam itu sendiri, melainkan demi kepentingan manusia. Perlu diperhatikan, bahwa hingga pada titik ini, ekoteologi berbicara "mewakili" alam yang telah rusak. Keindah-kudusan ciptaan belum ditilik secara sadar dalam diskursus ekoteologi maupun filsafat lingkungan hidup.

\section{ALLAH SANG KREATIVITAS-TAK-TERDUGA}

Gordon D. Kaufman, seorang teolog konstruktif dari abad ke-20, berpendapat bahwa misteri memiliki dimensi estetis yang dapat menghantarkan seseorang pada perasaan kagum, heran 
dan terpesona (Kaufman, 1993: 59). Kaufman beranggapan bahwa imajinasi manusia berusaha untuk memahami konteks misterius yang melingkupi kehidupan ini. Tanpa imajinasi mengenai dunia sekitarnya, manusia tidak akan dapat mengorientasikan dirinya di hadapan sang Misteri. Oleh karena itu, ia beranggapan bahwa yang dapat kita pahami hanyalah bagian partikular dari keseluruhan kehidupan (Kaufman, 1993: 114).

Kaufman secara holistik mengulas empat skema kategoris dalam bukunya In Face of Mystery, yakni: Allah, manusia, dunia, dan Kristus. Allah terus bekerja dalam dunia dan akhirnya akan membawa seluruh ciptaan pada konsumasi, yakni pada Allah sendiri (Kaufman, 1993: 45). Sementara itu, manusia dan dunia tidak dapat dipahami secara terpisah. Manusia tidak dapat dimengerti tanpa dunia sebagai konteksnya. Dunia tidak dapat dimengerti tanpa manusia sebagai makhluk yang hidup di dalamnya. Kaufman menyatakan bahwa, "They gain their being and their meaning from their relationship to God, their place in God's purposes, and it is only in this connection that what they are, and what they should do and become, can be rightly grasped" (Kaufman, 1993: 73).

Dalam karya besarnya tersebut, Kaufman pun menyebutkan bahwa dunia berotasi di seputar pengertian manusia. Pemahaman mengenai Allah sebagai Realitas Ultima juga berkembang sesuai dengan pengertian manusia. Menurut saya, Kaufman menyatakan kritik ekologisnya ketika menyebutkan bahwa, "Nature with its enormous variety of modes of being and life all in complex structural interconnection, does not have a significance here in any way comparable to that of humanity. Nature functions largely to provide stage setting and props for the central dramatic action which transpires between God and humans" (Kaufman, 1993: 76). Seperti yang telah saya sebutkan sebelumnya, Kaufman pun menyatakan bahwa alam semesta berfungsi hanya sebagai latar belakang bagi aksi dramatis yang terjadi antara Allah dan manusia.

Menurut Kaufman, manusia adalah bagian dari “complex web of life” di alam semesta ini. Manusia terhubung pada segala bentuk kehidupan. Manusia tidak lebih dari sebuah bagian yang sangat kecil (tiny moment) dari ekosistem yang lebih besar, yakni bumi. Bumi pun merupakan bagian yang sangat kecil pula dari alam semesta (Kaufman, 1993: 106). Manusia tidak dapat dimengerti sebagai sebuah realitas independen. Manusia hanya dapat dimengerti dalam konteksnya, yakni kehidupan yang saling terhubung dan tidak terpisah dari dunia (Kaufman, 1993: 112). Sementara itu, dunia yang ditinggali manusia bersifat evolusioner, yang senantiasa bergerak dan berkembang seiring waktu. Jejak proses perkembangan alam semesta ini dapat ditelusuri secara saintifik bahkan hingga ke jutaan tahun yang lalu. Alam semesta ini bergerak menuju "open-ended future" secara evolusioner dan historis (Kaufman, 1993: 239). Ia menyatakannya secara jelas bahwa, "They belong to each other, and they complement each other" (Kaufman, 1993: 115). 
Kaufman meyakini bahwa model Allah yang antroposentris dapat memiliki konsekuensi yang koruptif dan destruktif terhadap lingkungan hidup (Kaufman, 1993: 78). Pandangan mengenai Allah sebagai Pencipta dan Penyelamat umat sangat dekat dengan paham antroposentrisme. Oleh karena itu, secara konstruktif, Kaufman menawarkan konsep Allah yang ia lihat sebagai Kreativitas-Tak-Terduga (Serendipitious Creativity).

Kaufman menggunakan kata emergence sebagai metafora untuk menggambarkan proses ini. Emergence berarti kemunculan suatu realitas yang baru pada suatu kondisi yang tepat. "Kehidupan" muncul dari "materi"; "kesadaran" muncul dari "kehidupan"; dan sebagainya. Kemunculan setiap realitas memiliki pola dan potensialitas yang berbeda dari yang sebelumnya. Kata emergence menunjukkan bahwa dunia terdiri dari berbagai bentuk realitas yang baru dan tak terduga. Dunia tidak dapat dipahami sebagai sebuah struktur yang konstan dalam pola yang berulang. Dunia justru dipahami sebagai sebuah tatanan yang di dalamnya hal-hal yang belum ada dapat menjadi ada. Ia menyatakan bahwa, "It is an order in which the new can happen in the course of time, a world in which significant creativity occurs. In evolutionary processes emergence is piled on emergence, creativity on creativity" (Kaufman, 1993: 259).

Allah adalah Kreativitas-Tak-Terduga yang tak kasat mata namun senantiasa memperbarui dan mentransformasi ciptaan. Dunia tidak dapat merangkul kehidupan seluruh ciptaan apabila tata ciptaan terlalu determinatif. Oleh karena itu, harus ada keterbukaan atau kelonggaran yang memungkinkan terjadinya Kreativitas-Tak-Terduga tanpa henti yang memberikan ruang bagi makhluk hidup untuk beraktivitas (Kaufman, 1993: 239). Kreativitas-Tak-Terduga ini, yakni Allah, adalah dasar dari segala realitas, yang menciptakan segala sesuatu, termasuk makhluk hidup dengan historisitas dan kebebasannya (Kaufman, 1993: 245).

Oleh karena Allah yang menciptakan alam semesta adalah Kreativitas-Tak-Terduga, maka alam semesta ini pun merupakan alam-semesta-tak-terduga pula. Alam-semesta-tak-terduga ini merupakan konteks dari eksistensi manusia. Kreativitas-Tak-Terduga mengekspresikan diri dalam bentuk evolusi kosmos dan dalam sejarah kehidupan, termasuk kehidupan manusia (Kaufman, 1993: 342). Alam semesta yang di dalamnya Kreativitas-Tak-Terduga mengekspresikan diri secara mengejutkan. Menurut Kaufman, Kreativitas-Tak-Terduga ini termanifestasi dalam seluruh alam semesta (Kaufman, 1993: 268). Kreativitas-Tak-Terduga dapat dilihat melalui beragamnya proses genetik, yang membentuk organisme beragam jenis pula, tergantung kepada lingkungan habitat mereka. Kreativitas-Tak-Terduga ini menjadi jawaban terhadap kompleksnya bentuk kehidupan. Tidak dapat dibantah bahwa Kreativitas-Tak-Terduga yang kompleks inilah yang membawa dan melahirkan bentuk-bentuk kehidupan yang baru ke dalam ruang dan waktu. 


\section{KEINDAH-KUDUSAN SEMESTA}

Karl Rahner menyatakan bahwa keseluruhan teologi Kristen harus bersifat subjektif. Teologi tidak dapat berbicara mengenai hal di luar realitas subjek, baik yang bersifat spiritual maupun material. “Kita tidak dapat membuat pernyataan teologis mengenai seekor kumbang” (Rahner, 1992, 165). Melalui bukunya Ask the Beasts (2014), Elizabeth A. Johnson justru ingin mengkritik pernyataan Rahner dengan merefleksikan kumbang dan ciptaan lain di luar manusia, bahkan membuat mereka menjadi subjek religius. Flora, fauna, tanah, udara, dan lautan, akan membawa pikiran dan hati manusia kepada Allah yang murah hati. Dalam keindahan, keragaman, interaksi mereka, mereka menyaksikan kebaikan yang melimpah dari Pencipta mereka. Mereka bahkan mengajarkan sesuatu tentang manusia, bahwa setiap anggota komunitas kehidupan menerima nafas mereka sebagai anugerah dari Pemberi Kehidupan yang sama sekali tak ternilai.

Namun demikian, menurut Johnson, “Theology lost touch with universe” (Johnson, 2014: 3). Secara keliru dunia dipandang sebagai anugerah yang diciptakan Allah semata-mata untuk dimanfaatkan oleh manusia. Di sisi lain, sains dan teknologi dianggap sebagai penemuan manusia yang, meskipun baik, dapat berdampak merusak alam. Sains menganggap dunia sebagai sistem terstruktur yang beroperasi sesuai hukum alam. Namun, proses evolusi memungkinkan segala sesuatu yang baru dapat terjadi. Dunia yang memungkinkan kreativitas dapat terjadi (Kaufman, 1993: 259). Ada Kreativitas-Tak-Terduga yang menopang seluruh proses kehidupan di semesta. Kreativitas-Tak-Terduga ini adalah sisi lain dari alam semesta, wajah semesta yang tersembunyi dari manusia.

Bruce Foltz, seorang teolog dan filsuf lingkungan hidup, dalam buku The Noetics of Nature (2014), menyatakan bahwa:

\footnotetext{
"In the ancient thought and spirituality of Byzantium — which is still very much a living tradition in the Orthodox East, and increasingly in Western Europe and North America - and in its more distant spiritual relatives both East and West, important insights and realizations can be found that will shed an indispensible light (one for which neither scientific theory nor philosophical reflection nor practical logistics on their own can substitute) upon what it would take to sustain a happier, more salutary relation between humanity and an earth whose holiness can still shine forth like shook foil, and that we may therefore still be able to inhabit poetically" (Foltz, 2014: xv).
}

Kekristenan Orthodoks memiliki banyak ruang bagi alam semesta dalam tradisinya. Kekristenan Nusantara, yang notabene mewarisi tradisi kekristenan Barat, perlu menilik tradisi Kristen Timur. Foltz secara kreatif meramu tradisi kekristenan Orthodoks dan filsafat lingkungan hidup. Menurutnya, seluruh ciptaan di jagat raya indah dan kudus. Ia menawarkan visi noetis 
sebagai cara untuk memandang dan memaknai keindah-kudusan semesta. Sang Kudus yang termanifestasi dalam setiap ciptaan menghadirkan epifani yang melegakan bagi mereka yang melihat dengan visi noetis.

Foltz menawarkan visi noetis sebagai usaha untuk melihat yang tidak terlihat di dalam yang kasat mata. Ia menuliskan:

\begin{abstract}
"Yet this noetic vision is itself precisely the ability to see the invisible within the visible (i.e., the ability to see all creation in its iconic character). Our iconic being is manifested in our iconic seeing: We actively image the invisible divinity when we see the traces of invisible divinity in creation... This noetic vision, then, this iconic seeing, this seeing of the invisible within the visible, is just as much the ability to apprehend beauty: the beauty of the icon and the beauty of the earth as well. The logoi of created things, the presence of the invisible within them, is at the same time their hidden beauty that can be apprehended by noetic vision" (Foltz, 2014: 147).
\end{abstract}

Tradisi Orthodoks selalu melihat keselamatan sebagai peristiwa kosmik ditebusnya seluruh isi alam semesta. St. Maximus Confessor, biarawan dari abad ketujuh, menggambarkan peristiwa inkarnasi Allah sebagai penyempurnaan tatanan cipta. Setiap ciptaan memiliki Firman Kekal secara partial di dalamnya, oleh karena itu, setiap ciptaan mencerminkan Penciptanya (Foltz, 2014: 1112). St. Basilius dari Kaesarea memandang alam semesta sebagai karya seni Allah. Ia memakai metafora teori dan karya seni untuk menunjukkan bahwa alam merupakan mahakarya Allah. Sebuah teori seni belum dapat disebut sebagai karya seni. Teori tersebut harus diterjemahkan ke dalam bentuk-bentuk artistik dan maknawi terlebih dulu. Ketika teori tersebut menjadi karya seni, maka ia menjadi sebuah karya yang bertahan. Demikian juga dalam seni arsitektur maupun seni pahat. Karya seni tetap tinggal dalam imajinasi penikmat seni dan seniman tersebut tetap dikagumi meskipun pentas telah usai. St. Basilius mengagumi Allah sebagai Seniman yang agung karena telah menciptakan alam semesta dengan segenap keindahannya (St. Basilius, Hexaemeron I/VII).

Dengan hikmat Ia menciptakan seluruh semesta. Kitab Kejadian menunjukkan Allah, yang oleh Kaufman disebut sebagai Kreativitas-Tak-Terduga, menjadikan alam semesta ini, seperti seorang seniman menciptakan mahakaryanya, menyatukan ciptaan yang satu dengan yang lain dalam keterhubungan satu dengan yang lain, dan menjadi mahakarya yang megah dan ilahi. Dengan apik, St. Basilius mengajak manusia bersama dengan seluruh ciptaan untuk memuji Allah dalam kebesaran-Nya:

"Let us glorify the supreme Artificer for all that was wisely and skillfully made; by the beauty of visible things let us raise ourselves to Him who is above all beauty; by the grandeur of bodies, sensible and limited in their nature, let us conceive of the infinite Being whose immensity and omnipotence surpass all the efforts of the imagination" (St. Basilius, Hexaemeron I/XI). 
Keindah-kudusan ciptaan tidak terlihat karena semakin hilangnya sensasi transendental di dalam kosmologi modern. Bruce Foltz berargumen bahwa manusia harus menyadari keindahan alam adalah kudus dan keindah-kudusan tersebut terberi begitu saja ketika Allah, Sang IndahKudus, menciptakan seluruh jagat raya. Pertimbangan estetis termarjinalkan dalam diskursus filsafat lingkungan hidup. Foltz menyatakan bahwa alam harus dilindungi karena keindahannya. Sang Kudus berdiam dalam keindahan alam dan mentransformasi keindahan alam menjadi keindahan yang kudus pula (Foltz, 2014: 30).

Bagi St. Basilius, Allah tidak melihat dan menilai keindahan karya-Nya seperti manusia, karena Allah tidak memaknai keindahan seperti manusia memaknai keindahan. Tanah Bumi yang gembur merupakan "perfect finishing” dari proses penciptaan karena di tanah yang subur segenap jenis tumbuhan dapat hidup (St. Basilius, Hexaemeron II/I). Namun, manusia tengah dan telah merusak kesuburan tanah dan bersalah karena merusak "finishing” tersebut.

Alam semesta adalah sebuah kesatuan, sebuah keseluruhan terstruktur. Pada karya seni patung manusia, jika bagian tangan, kaki, atau mata terpisah dari badan, maka onggokan patung tersebut tidak memiliki sisi artistik dan tidak akan bermakna apa-apa. Akan tetapi, seorang seniman akan menyatukan dan melihat patung manusia tersebut secara keseluruhan sekaligus mengagumi bahwa karena tiap bagian partikular dari tubuhlah yang menjadikan patung tersebut bermakna artistik. Alkitab menggambarkan bagaimana Allah mengagumi mahakarya yang dijadikan-Nya satu per satu. Manusia memiliki intuisi keindahan. Mata manusia menyukai keindahan. Tubuh manusia bereaksi dengan mengeluarkan hormon-hormon kebahagiaan ketika melihat atau bersentuhan dengan hal-hal yang indah. Keindah-kudusan alam mampu menghadirkan sensasi Kreativitas-Tak-Terduga dan setiap orang secara naluriah memiliki sensibilitas terhadap keindahkudusan ini (St. Basilius, Hexaemeron III/X).

\section{SOPHIANICITY OF THE WORLD}

Dunia berotasi di seputar pengertian manusia. Referensi Ultima, Allah dalam bahasa Kaufman, yang dari-Nya segala sesuatu memiliki asal, juga dipahami dalam definisi antroposentris ini. Bagaimana konteks menyeluruh seluruh kehidupan di planet Bumi dipahami secara teologis? Apa artinya berbicara tentang Allah di dunia, yang menurut sains modern, berasal dari "ledakan besar" lima belas miliar tahun yang lalu?

Klaim teologis harus tetap relevan dengan kebutuhan dunia. Oleh karena itu, klaim teologis harus saling terhubung dan senantiasa dialogis dengan paham kosmologi, evolusi, dan ekologi. 
Menurut Kaufman, sebagian besar teologi kontemporer hampir mengabaikan tugas ini dan secara tidak langsung telah berkontribusi melemahkan makna "Allah" di dunia intelektual modern. Menurut Kaufman, makna kehidupan manusia saat ini dapat ditemukan dari permenungan akan makna Allah (Kaufman, 1993: 12). Allah adalah Referensi Ultima yang dari-Nya manusia dan dunia mendapatkan maknanya. Lalu, apa makna Allah bagi para ekoteolog dan bagaimana hal tersebut memengaruhi teologi kita mengenai alam?

Setiap ciptaan memiliki jejak Allah. Jejak Allah dapat diketahui melalui apa yang telah dimanifestasikan oleh alam dengan segala kompleksitasnya. Teologi perlu menyadari bahwa semakin banyak flora dan fauna yang punah karena perbuatan manusia, semakin rusaknya tempat hidup bersama berbagai jenis makhluk hidup, semakin hancurnya keanekaragaman hayati akibat perbuatan destruktif manusia, manusia akan semakin sulit mengenal Allah karena hilangnya jejakjejak tersebut.

St. Basilius mengakui bahwa Hikmat-Kosmis yang berdiam dalam seluruh ciptaan selalu berhasil membangunkan rasa takjub dalam dirinya (St. Basilius, Hexaemeron VII/V). Allah mengesankan bagi St. Basilius karena Ia telah memanifestasikan hikmat-Nya ke dalam seluruh semesta. Hikmat Allah yang membuat semut-semut hidup bekerja sama. Hikmat Allah yang membuat hewan-hewan berpindah dari tempat yang dingin ke tempat yang hangat pada musim dingin.

Teologi Orthodoks memahami Hikmat Kosmis ini sebagai Sophia. Sophia merupakan pusat kehidupan iman Orthodoks. Kitab-kitab hikmat seperti Amsal, Kebijaksanaan Salomo, dan Sirakh sangat kaya dengan konsep Sophia. Sophia adalah Hikmat-Kosmis yang kreatif yang menopang seluruh ciptaan dalam cinta. Sophia mengenal segala yang tersembunyi dan yang terlihat. Sophia itu arif, kudus, jernih, tidak bernoda, terang, tidak dapat dirusak, murah hati, dan murni. Sophia adalah pantulan cahaya Allah yang kekal dan gambaran kebaikan Allah (Keb. 7:21-26).

Seluruh semesta dirangkul dan berakar dalam Sophia. Vladimir Solovyov melihat penebusan dan penyelamatan Allah dalam penglihatannya akan Sophia, Hikmat Ilahi yang menghubungkan Allah dan alam. Ia memahami Sophia sebagai yang tertinggi dan yang merangkul seluruh ciptaan bahkan seluruh kosmos, menyatu dengan Allah dari kekal, yang menyatukan Allah dengan segala yang ada (Solovyov, 2001: 58). Inkarnasi dilihat sebagai glorifikasi terhadap ciptaan, dan kebangkitan orang mati dimaknai sebagai penyempurnaan dan transformasi segala isi dunia. Pemahaman ini mendasari pemikiran Solovyov tentang Sophia sebagai dasar dari estetika universal. Solovyov melihat keindahan seperti kilau yang menyingkapkan kepenuhan dan keutuhan alam itu sendiri. Seperti Plato, bagi Solovyov keindahan dapat menampilkan sekelibat bayangan yang tidak terlihat melalui yang terlihat. 
Di sisi lain, menurut Sergius Bulgakov, murid dari Vladimir Solovyov, Sophia menyediakan standar kehidupan ideal yang ia sebut sebagai edenic economy, yakni kehidupan yang mengembalikan dan mentransfigurasi seluruh kosmos seperti semula (prototipe/edenic) (Foltz, 2014: 106). Dalam tradisi kekristenan Orthodoks, manusia memiliki peran sebagai imam kosmis yang berperan sebagai perantara antara Allah dan kosmos. Oleh karena peran kosmis ini, ketika manusia jatuh ke dalam dosa, maka alam semesta pun ikut jatuh ke dalam dosa. Meskipun demikian, saya memiliki keberatan tersendiri terhadap peran imam kosmis tersebut, karena konsep ini sangat mengutamakan manusia dalam tatanan cipta dan menyamaratakan dosa alam dan manusia. Sementara itu, di sisi lain, manusia justru berdosa karena merusak kesempurnaan ciptaan non-manusia.

Bagi Bulgakov, Sophia, sebagai Hikmat-Kosmis yang merupakan keterjalinan tertinggi dari segala sesuatu yang ada, tidak dapat dipahami secara saintifik, karena sains mengamati formula dan pola yang terjadi (Bulgakov, 2000: 183-184). Hikmat-Kosmis ini berdiam dalam seluruh ciptaan dan menopang ciptaan. Hikmat-Kosmis adalah Logos. Bagi St. Maximus Confessor, seluruh ciptaan memiliki logoi masing-masing. Bulgakov sejalan dengan pemikiran ini. Seluruh semesta merupakan kepenuhan logoi (Bulgakov, 2004: 208).

Sophia adalah keindahan yang senantiasa aktif dalam setiap makhluk menuju Logos Kekal, yakni Kristus itu sendiri (Bulgakov, 1999: 140). Keindahan adalah "exteriorized sophianicity" ciptaan, pantulan cahaya Sophia (Bulgakov, 1999: 202). Keindah-kudusan alam memiliki energi spiritual yang menguatkan keterikatan antara manusia dengan seluruh semesta. Sophia adalah kemurnian dan kesempurnaan seluruh semesta dan dinyatakan melalui keindah-kudusan ciptaan (Bulgakov, 1999: 151).

Pavel Florensky, seorang filsuf dan teolog Orthodoks Timur, rekan dari Sergius Bulgakov, menggambarkan bahwa Sophia adalah keseluruhan ciptaan, namun tidak semata-mata semua ciptaan. Sophia adalah "the Great Root" yang melaluinya seluruh ciptaan dapat berpartisipasi ke dalam hidup intra-Trinitarian. Sophia adalah natur orisinal ciptaan (Florensky, 1997: 137). Bagi Florensky, Sophia merepresentasikan spiritualitas ciptaan, kekudusan dan kemurnian ciptaan (Florensky, 1997: 253). Ciptaan, dalam keutuhannya, menunjukkan bahwa keindahan adalah manifestasi Sophia yang paling esensial (Foltz, 2014: 37). Di dalam keindah-kudusan, hikmat Allah yang melaluinya seluruh kosmos diciptakan, dapat dijumpai.

\section{SEMARAK KUDUS CUKUP UNTUK SEGALA}

"The World is charged with the grandeur of God.

It will flame out, like shining from shook foil” (Hopkins, 2014: 39). 
Puisi di atas merupakan penggalan dari karya terkenal sastrawan Gerard Manley Hopkins yang berjudul God's Grandeur. Kata grandeur dalam The New Oxford American Dictionary berarti 'splendor' atau 'impressiveness' yang dalam bahasa Indonesia berarti 'semarak', 'kemegahan', atau 'hal yang mengesankan'. Dunia dipenuhi oleh kemegahan Allah yang bersinar seperti kilat api. Akan tetapi, saya mengusulkan membaca dan memaknai frasa God's grandeur bukan sebagai grandeur of God. God's Grandeur justru dapat dibaca God is Grandeur-Allah adalah Semarak itu sendiri.

Judul makalah ini saya sadur dari tulisan Elizabeth A. Johnson yang terinspirasi oleh kalimat pertama dalam paragraf terakhir mahakarya Charles Darwin, yakni On the Origin of the Species. Darwin menuliskan, "There is grandeur in this view of life" (Darwin, 2009: 490). Dengan memahami bahwa "God is the Grandeur itself", saya pun membaca kalimat Darwin tersebut dengan "There is Grandeur in this view of life". Jika Darwin memahami bahwa ada kemegahan yang semarak dalam hidup ini, maka saya memahami bahwa ada Semarak Kudus dalam hidup ini. Ada Semarak Kudus yang senantiasa berekspresi di dalam dan melalui ciptaan. Ada Semarak Kudus yang membuat manusia dapat melihat keindah-kudusan ciptaan. St. Basilius menuliskan, "Therefore, when you see the trees in our gardens, or those of the forest, those which love the water or the land, those which bear flowers, or those which do not flower, I should like to see you recognizing grandeur even in small objects" (St. Basilius, Hexaemeron V/IX).

Allah adalah Semarak Kudus yang berdiam dalam semesta, bahkan dalam ciptaan paling kecil sekalipun. Semarak Kudus yang menopang seluruh ciptaan dalam proses evolusi menuju konsumasi, finalitas ciptaan, yaitu pada Allah sendiri. Semarak Kudus yang secara kreatif dan tanpa henti memunculkan kehidupan-kehidupan baru di Bumi yang mengejutkan namun menyukacitakan. Semarak Kudus dapat ditemui dalam setiap perjumpaan dengan alam semesta beserta keindahkudusannya. Puisi Hopkins menunjukkan sakramentalitas alam semesta dan pengalaman religius yang dirasakan oleh orang-orang yang membiarkan dirinya berinteraksi dengan alam bebas, baik tanaman maupun hewan.

Jika manusia dapat tersadar akan keberlimpahan dan keindah-kudusan dunia, jatuh cinta dan menghargai kehidupan, bukan hanya kehidupan manusia, tetapi segala bentuk kehidupan, dan mengubah perilaku destruktif untuk melindunginya, sebagian besar kerusakan yang terjadi mungkin bisa dikendalikan secara perlahan.

"But let us come out of the depths of the sea and take refuge upon the shore. For the marvels of creation, coming one after the other in constant succession like the waves, have submerged my discourse. However, I should not be surprised if, after finding greater wonders upon the earth, my spirit seeks like Jonah's to flee to the sea. But it seems to me, that meeting with these innumerable marvels has made me forget all measure" (St. Basilius, Hexaemeron VII/V). 
St. Basilius memberikan contoh hubungan dengan alam yang sangat manis. Ia mengajak pembacanya untuk berinteraksi dengan alam. Ketika melihat pepohonan di kebun atau hutan, bunga yang sedang mekar, kenalilah keagungan Semarak Kudus bahkan pada benda-benda kecil yang ada di sana. Biarkanlah keajaiban semesta menggerakkan hatimu seperti hati Yunus tergerak untuk segera terjun ke dalam laut!

\section{BERSEMARAK BERSAMA ALLAH}

Sebagian besar alam telah dan sedang rusak. Sebagian lainnya basah dan gembur. Ekoteologi dan filsafat lingkungan hidup senantiasa berbicara mewakili sisi alam yang rusak. Akan tetapi, sisi yang lain, alam yang indah dan masih terjaga, terluput dari perbincangan. Keindahan ciptaan adalah kudus karena diciptakan oleh Sang Indah-Kudus. Setiap ciptaan memiliki jejak Allah. Semakin banyak flora dan fauna yang punah karena perbuatan kita, semakin rusaknya tempat hidup bersama berbagai jenis makhluk hidup, semakin hancurnya keanekaragaman hayati akibat perbuatan destruktif manusia, akan semakin sulit kita mengenal Allah karena hilangnya jejak-jejak tersebut. Namun, kita belum kehilangan harapan. Ekoteologi perlu merenungkan bahwa Allah, Sang Semarak Kudus, yang memanifestasikan hikmat-kosmis dalam keindah-kudusan seluruh ciptaan, cukup untuk segala. The Holy Grandeur is enough for all!

\section{Catatan}

${ }^{1}$ Lihat dalam buku Elizabeth A. Johnson (2014: 18).

\section{DAFTAR RUJUKAN}

Basilius, The Great. 2007. "Hexaemeron (Homily 1): In the Beginning God Made the Heaven and the Earth", http://www.newadvent.org/Ensiklopedia/fathers/32011.htm (diakses 09.05.2017).

. 2007. "Hexaemeron (Homily 2): The Earth was Invisible and Unfinished", http://www. newadvent.org/Ensiklopedia/fathers/32012.htm (diakses 09.05.2017). 
. 2007. "Hexaemeron (Homily 3): On the Firmament", http://www.newadvent.org/ Ensiklopedia/fathers/32013.htm (diakses 09.05.2017).

. 2007. "Hexaemeron (Homily 5): The Germination of the Earth", http://www.newadvent. org/Ensiklopedia/fathers/ 32015.htm (diakses 09.05.2017).

. 2007. "Hexaemeron (Homily 7): The Creation of Moving Creatures", http://www. newadvent.org/Ensiklopedia/fathers/32017.htm (diakses 09.05.2017).

Borrong, Robert Patannang. 2005. Environmental Ethics and Ecological Theology: Ethics as Integral Part of Ecosphere from an Indonesian Perspective, Amsterdam: Vrije Universiteit.

Bulgakov, Sergius. 2000. Philosophy of Economy: The World as Household, trans. Catherine Evtuhov, New Haven: Yale University Press. . 2004. The Comforter, trans. Boris Jakim, Grand Rapids: Wm. B. Eerdmans. . 1999. The Unfading Light, ed. Rowan Williams, Edinburgh: T\&T Clark.

Darwin, Charles. 2009. The Annotated Origin: A Facsimile of the First Edition of on the Origin of Species, annotated by James Costa. Cambridge, MA and London: Belknap Press of Harvard University Press.

Florensky, Pavel. 1997. The Pillar and Ground of the Truth, trans. Boris Jakim, Princeton: Princeton University Press.

Foltz, Bruce V. 2014. The Noetics of Nature: Environmental Philosophy and the Holy Beauty of the Visible, New York: Fordham University Press.

Francis, Pope. 2015. Laudato Si': On Care for Our Common Home, Vatican: Vatican Press.

Hopkins, Gerard Manley. 2014. Poems: 1876-1889, Omaha: William Ralph Press.

Gschwandtner, Christina M. 2012. The Role of Non-human Creation in the Liturgical Feasts of the Eastern Orthodox Tradition: Towards an Orthodox Ecological Theology, Theses, Durham: Durham University.

Jenkins, W. 2008. Ecologies of Grace, New York: Oxford University Press.

Johnson, Elizabeth A. 2014. Ask the Beasts: Darwin and the God of Love, London: Bloomsbury Publishing.

Migliore, Daniel L. 2014. Faith Seeking Understanding: An Introduction to Christian Theology, Grand Rapids: Wm. B. Eerdmans Publishing.

Moltmann, Jurgen. 1985. God in Creation, London: SCM Press Ltd. 
Rahner Karl. 1992. "Art Against the Horizon of Theology and Piety”, Theological Investigations, Volume 23, New York: Crossroad.

Solovyov, Vladimir. 2001. "The Collapse of the Medieval World-Conception," in A Solovyov Anthology, ed. S.L. Frank, London: St. Austin Press.

Van Dyk, Peet J. 2011. “Responsible Stewardship_-The Root of All Evil in Eco-Theology?”, Old Testament Essays, Volume 24/2, p. 523-535.

White Jr., Lynn. 1967. “The Historical Roots of Our Ecologic Crisis”, Science, Vol. 155, No. 3767 (Mar. 10, 1967), USA: American Association for the Advancement of Science, pp. 12031207.

World Wide Fund. "WWF”, http://wwf.panda.org/what_we_do/where_we_work/coraltriangle/ (retrieved May 8, 2017). 